\title{
Aplikasi Teori Osgood untuk Evaluasi Pemaknaan Internal Strategi Komunikasi Pemasaran Co-branding
}

\author{
Rachmat Kriyantono \\ Program Studi Magister Ilmu Komunikasi, Universitas Brawijaya \\ J1. Veteran Malang, 65145 Indonesia \\ Telp: 082142538278 \\ Corresponding author: rachmat kr@ub.ac.id
}

\begin{abstract}
The research aims to apply Osgood's semantic meaning theory and semantic differential scale to evaluate cobranding products strategy. The first hypothesis formulated is that co-brand products have a different meaning from potential consumers even though the product is identical. The second hypothesis is that the parent brand gets a more positive meaning - evaluation, activity, potential. By conducting a survey on 111 students, the hypotheses are established. The findings also confirm some factors that determine the effective of co-branding strategy, such as the respondents 'perceptions, the parent brand, the companies or brands equity, and the ability of the companies to meet the products with the consumers'needs. The research contributes to develop the study of marketing communication in Indonesia, particularly the subject of co-branding. There is surprisingly little quantitative empirical research on the subject from the scholars although co-branding products have been in use for some time as external stimulus to the consumers in marketing communication.
\end{abstract}

Keywords: Co-branding; Marketing Communication; Osgood theory; Semantic Differential; Semantic Meaning

\begin{abstract}
Abstrak
Penelitian ini bertujuan untuk menerapkan teori makna semantik (Semantic Meaning) dan skala diferensial semantik (Semantic Differential Scale) dari Osgood untuk mengevaluasi produk co-branding, sebagai strategi komunikasi pemasaran. Hipotesis pertama yang dirumuskan adalah produk co-brand memiliki makna yang berbeda dari konsumen potensial walaupun produk tersebut identik. Hipotesis kedua adalah merek induk mendapatkan makna yang lebih positif - evaluasi, aktivitas, potensi. Penelitian ini menggunakan metode kuantitatif dengan pendekatan survei terhadap 111 mahasiswa, hipotesis penelitian telah dibuktikan. Temuan ini juga mengonfirmasi beberapa faktor yang menentukan efektivitas strategi co-branding, seperti persepsi responden, merek induk, perusahaan atau ekuitas merek, dan kemampuan perusahaan untuk memenuhi produk dengan kebutuhan konsumen. Penelitian memberikan kontribusi untuk mengembangkan studi komunikasi pemasaran di Indonesia, khususnya subjek co-branding. Sangat sedikit penelitian empiris kuantitatif dari para akademisi di bidang ini meskipun co-branding telah digunakan sebagai stimulus eksternal kepada konsumen dalam komunikasi pemasaran.
\end{abstract}

Kata kunci: Co-branding; Komunikasi Pemasaran; Teori Osgood; Semantic Diferensial; Semantic Meaning

\section{Pendahuluan}

Penelitian ini menganggap bahwa Teori Makna Semantik dari Charles Osgood (Teori Osgood) memainkan peran penting sebagai alat untuk strategi komunikasi pemasaran meskipun berakar dari bidang psikologi (Kriyantono, 2017; Lukyandari, 2014). Teori ini kemudian diadopsi dalam kajian Ilmu Komunikasi dan masuk dalam ranah tradisi sosio-psikologis (Craig, 2007; Griffin, 2013; Littlejohn, Foss, \& Oetzel, 2017). Teori ini membahas bagaimana pesan harus dipahami karena makna internal dalam pikiran individu dihasilkan oleh stimulus atau pesan dari luar (Craig, 2007; Griffin, 2013; Littlejohn et al. 2017), dan "Pemaknaan internal ini menghasilkan respons ke luar" (Littlejohn et al. 2017, h. 190).

Osgood, Suci, dan Tannenbaum (1957) memperluas Teori Makna Semantik dengan menawarkan diferensial semantik sebagai alat ukurnya. Pengukuran ini mengasumsikan bahwa seseorang dapat mengekspresikan maknanya dengan menggunakan berbagai kata atau konotasi kata sifat. Secara umum, perbedaan semantik mengelompokkan ekspresi konotasi 
individu untuk beberapa stimulus menjadi tiga dimensi kata sifat, yaitu evaluasi (baik atau buruk), aktivitas (aktif atau pasif), dan potensi (kuat atau lemah). Osgood et al (1957) menyebut tiga dimensi makna semantik tersebut sebagai ruang semantik (semantic space).

Tiga dimensi penandaan (makna) tersebut terjadi dalam berbagai konteks, yakni berlaku untuk semua orang dan semua konsep (Khan, 2007; Lttlejohn et al. 2017; Osgood et al. 1957), dan menjadi objek studi, seperti Sosiologi (Strunga, 2014 ), Ilmu Komunikasi (Craig, 2007; Griffin, 2013; Littlejohn et al. 2017), manajemen pendidikan, bahasa dan studi lintas budaya (Finstuen, 1977), dan riset pemasaran dan bisnis (Finstuen, 1977; Khan, 2007; Sharpe \& Anderson, 1972). Beberapa penelitian diferensial semantik telah dilakukan dalam bidang bisnis (Finstuen, 1977). "Terdapat sedikit upaya sistematis yang ditujukan untuk menerapkan teknik ini dalam konteks pemasaran" (Sharpe \& Anderson, 1972, h. 432), dalam penelitian ini, teori diferensial semantik diterapkan untuk mengukur pemaknaan individu pada produk co-branding, stimulus eksternal kepada konsumen potensial, sebagai bagian dari strategi komunikasi pemasaran.

Memahami pemaknaan internal konsumen terhadap produk sangat penting untuk mengetahui citra produk, yang dapat membangun loyalitas merek (brand loyalty), karena loyalitas merek merupakan target penting yang ingin dicapai melalui proses branding (Heding, Knudtzen, \&, Jerre, 2009, p.13). Brand loyalty ini dapat mendorong ekuitas merek yang tinggi, yakni konsumen mengenal merk dengan baik saat ditanya atau saat membutuhkan suatu produk dalam kategori tertentu (Kriyantono, 2013).

Penelitian ini merupakan pengembangan dari penelitian Kriyantono (2017) sebelumnya tentang pemaknaan internal produk Avanza dan Xenia padakonsumen. Penelitian ini ingin membuktikan apakah hasil penelitian tersebut tetap berlaku dengan dua kondisi berbeda. Kondisi pertama adalah kelompok responden yang berbeda, yakni khusus responden dari kelompok mahasiswa. Selain itu, untuk meyakinkan pembuktian hipotesis sekaligus sebagai kondisi kedua, adalah munculnya dua produk co-branding yang lain dari dua perusahaan yang sama yang memproduksi Avanza dan Xenia, yakni peneliti juga meneliti Sigra dan Cayla. Hal tersebut menjadi pondasi penelitian yang bertujuan untuk menerapkan teori makna semantic (Semantic Meaning) dan skala diferensial semantik (Semantic Differential Scale) dari Osgood untuk mengevaluasi produk co-branding, sebagai strategi komunikasi pemasaran.

\section{Pengembangan Skala dalam Penelitian Komunikasi Pemasaran}

Beberapa penelitian telah mencoba mengembangkan indikator tiga dimensi Osgood (evaluasi, aktivitas, dan potensi) di bidang komunikasipemasaran. Sharpe\&Anderson(1972, h. 432-434) menawarkan dimensi agresivitas, dimensi stabilitas, dimensi kekencangan, dimensi kebaruan, dan dimensi penerimaan. Sharpe dan Anderson (1972) mempelajari enam variasi produk dan menggunakan diferensial semantik untuk membandingkan produk berdasarkan dimensi ini. Penelitian ini menggunakan analisis faktor konfirmatori untuk membentuk dan meyakinkan indikator atau untuk membuat faktor baru sehingga Teori Osgood dapat diterapkan di bidang studi lain.

Teori Osgood mengategorikan ekspresi makna menjadi tiga dimensi utama (evaluasi, aktivitas, dan potensi), masing-masing kategori melibatkan berbagai kata sifat (Littlejohn et al. 2017). Beberapa penelitian menawarkan subdimensi sebagai upaya untuk memperluas tiga dimensi utama. Vigneron dan Johnson (2004) menawarkan dua dimensi persepsi terhadap persepsi merek mewah non-pribadi dan pribadi. Dimensi non-pribadi melibatkan perhatian, keunikan, dan kualitas sedangkan persepsi pribadi melibatkan hedonisme dan perluasan diri. 
Colwell, Aung, Kanetkar, dan Holden (2008) melakukan survei cross-sectional dengan tujuan untuk melaporkan pengembangan dan pengujian nomologis skala 17 item untuk mengukur lima dimensi kenyamanan layanan (keputusan, akses, transaksi, manfaat, dan pasca-manfaat). Dalam mengembangkan item skala untuk masing-masing dari lima domain kenyamanan layanan ini, Colwell et al. (2008) melakukan 25 wawancara eksplorasi dengan konsumen mengenai pengalaman pribadi dengan penyedia layanan telepon seluler yang dipakai. Penelitian ini membangun skala untuk kenyamanan layanan yang terdiri dari lima item untuk masing-masing dimensi kenyamanan keputusan, kenyamanan akses, kenyamanan transaksi, kenyamanan manfaat, dan enam item untuk kenyamanan pasca-manfaat. Kepuasan keseluruhan diukur pada perbedaan semantik.

Khan (2007) mengevaluasi metodologi evaluasi pengalaman pengguna dan untuk mengidentifikasi metode yang dapat digunakan secara efisien untuk mengukur keseluruhan pengalaman pengguna dari penggunaan produk dari pengalaman pengguna menggunakan ponsel sebagai kasing. Metodologi diferensial semantik diidentifikasi sebagai metode yang paling sesuai berdasarkan metodologi evaluasi pengalaman pengguna saat ini dan kemudian digunakan untuk mengukur preferensi dari pengalaman pengguna secara keseluruhan yang dapat digunakan untuk meningkatkan bentuk produk untuk memastikan loyalitas pelanggan. Kuesioner ini didasarkan pada perbedaan semantik dari pasangan bipolar dari kata sifat yang dipilih yang paling menjelaskan aspek psikologis pelanggan, kualitas pragmatis dan hedonis dari produk ponsel dan mereka dipilih dari literatur yang digunakan secara eksplisit untuk evaluasi produk ponsel.

Lukyandari (2014) menemukan bahwa dimensi dari Colwell (2008) dan Vigneron dan Johnson (2004) kompatibel untuk mengukur persepsi konsumen terhadap produk co-branding. Oleh karena itu, Lukyandari mengintegrasikan merekakedalam Teori Osgooduntukmempelajari persepsi co-branding antara klub sepak bola dan penyedia telekomunikasi di Indonesia.

\section{Strategi Co-branding sebagai Stimulus Fisik dalam Teori Osgood}

Co-branding adalah penempatan atau penggabungan dua (atau lebih) nama merek pada satu produk untuk berkolaborasi untuk mencapai tujuan (Guillet \& Tasci, 2010; Leuthesser, Kohli, \& Suri, 2003; Kottler \& Keller, 2009; Mannan \& Bawa, 2005; Stewart, 2003). Wheeler (2009) menyatakan bahwa "co-branding is a teamwork done by some brands to make one product success together." Co-branding "mewakili strategi aliansi merek jangka panjang, yakni satu produk diberi merek dan diidentifikasi secara bersamaan oleh dua merek" (Helmig, Huber, \& Leeflang, 2008, h. 360). "Penggabungan dan penahanan dua atau lebih merek untuk menciptakan satu produk atau layanan." (Leuthesser, Kohli, \& Suri, 2003, hal. 36). "Co-branding adalah praktik menggunakan nama merek yang sudah mapan dari dua perusahaan yang berbeda untuk produk fisik yang sama" (Cao, 2012).

Co-branding adalah fenomena yang relatif baru dalam pemasaran (Guillet \& Tasci, 2010). Penelitian Norris (1992) dianggap sebagai yang pertama untuk merumuskan manfaat cobranding (Helmig et al. 2008; Srejeesh, 2012) dan penelitian empiris kuantitatif pada produk merek-bersama tidak dimulai hingga 1995 (Helmig et al, 2008). Baru-baru ini, co-branding semakin populer untuk mendapatkan kesuksesan komersial (Ahn \& Sung, 2011; Sreejesh, 2012; Singh, Kalafatis, \& Ledden, 2014) dan mendapatkan perhatian dari para manajer atau ilmuwan sebagai bentuk manajemen merek (Helmig et al. 2008) dan telah diterapkan di berbagai studi dalam bisnis dan manajemen (Ashton \& Scott, 2011). Ini menempatkan peran penting untuk membangun ekuitas merek, untuk memasuki pasar baru, untuk membantu merek yang tidak terkenal (Clow \& Baack, 2010, h. 
62-65), untuk menciptakan preferensi dan niat pembelian (Kurniawan, Suryoko, \& Listyorini, 2014), dan untuk menawarkan manfaat tambahan bagi konsumen, untuk mengurangi risiko ketika memasuki pasar baru, untuk meyakinkan konsumen, untuk meningkatkan penjualan, dan untuk menawarkan harga premium (Istiharini, 2006). "Ini adalah instrumen yang digunakan oleh pemasar pada spektrum yang luas, termasuk menciptakan kesadaran awal, keakraban, dan loyalitas pelanggan" (Gullet \& Tasci, 2010, h. 143). Co-branding memiliki efek positif dan signifikan pada ekuitas merek dan preferensi merek, kemudian, ekuitas merek mempengaruhi niat pembelian (Kurniawan, Suryoko, \& Listyorini, 2014).

Tercatat bahwa peran-peran itu tergantung pada bagaimana konsumen memandang kualitas, nilai, dan makna produk-produk cobrand sehingga tidak sepenuhnya berada dalam kendali pemasar (Askegaard \& Bengtsson, 2005; Clow \& Baack, 2010; Finne \& Gronroos, 2009). "Bagaimana pelanggan memandang cobranding menjadi prasyarat untuk menilai daya tarik relatif dari co-branding sehingga sebagian besar penelitian fokus pada persepsi pelanggan" (Leuthesser et al, 2003, h. 37). Penting pula makna dari konsumen dalam komunikasi pemasaran telah diterima dari beberapa penelitian (Finne \& Gronroos, 2009), namun, strategi cobranding perlu dieksekusi dengan hati-hati karena juga memiliki potensi risiko, seperti kedua merek menderita jika co-branding gagal (Clow \& Baack, 2010. Sebagai konsekuensinya, strategi co-branding membutuhkan perbedaan semantik sebagai ukuran untuk mengevaluasi dampaknya terhadap konsumen.

Penelitian saat ini berfokus pada bagaimana konsumen memandang Toyota Avanza dan Daihatsu Xenia, sebagai kendaraan serba guna (Multi-Purpose Vehicle, MPV) dan Toyota Cayla dan Daihatsu Sigra, sebagai mobil ramah lingkungan (Low Cost Green Car, LCGC) berbiaya rendah. Mobil-mobil tersebut memiliki karakter yang sama yang dipasarkan oleh dua merek yang berbeda, Toyota dan Daihatsu (Irawan, 2012; Kurniawan et al., 2014; Makur, 2017; Muzlie, 2018), sehingga merupakan cobranding yang saling melengkapi (Besharat \& Langan, 2014; Clow \& Baack, 2010), walaupun merekteratas, Toyotamemilikiekuitasmerekyang lebih tinggi daripada Daihatsu (Irawan, 2012).

Sejak 2003, Toyota mengambil alih Daihatsu dan menjadi merek induk dan pemilik Daihatsu (Irawan, 2012). Kendaraan tersebut diproduksi oleh Toyota Motor Corporation (Gunawanti, 2013). Kendaraan adalah fenomena luar biasa karena harga termurah untuk MPV dan LCGC. Sebelum diluncurkan, pesanan yang antri mencapai ribuan unit (Irawan, 2012). Kendaraan identik dalam desain mobil, tubuh, spesifikasi, dan promosi, tetapi Avanza dan Cayla lebih mahal (Gunawanti, 2013; Makur, 2017; Muzlie, 2018). MPV dan LCGC berhasil dalam penjualan sepuluh besar sejak diluncurkan, tetapi Avanza dan Cayla memiliki jumlah penjualan yang lebih tinggi (Irawan, 2012; Gunawanti, 2013; Makur, 2017; Muzlie, 2018; Sirait, 2016). Selama 2004-2010, Avanza berada di peringkat mobil terlaris diikuti oleh Xenia dan kedua merek mendominasi $78 \%$ dari pasar mobil. Avanza masih menjadi mobil terlaris, tetapi, Xenia berada di peringkat ke-7 selama 2014-2015 (Murdaningsih, 2016). Avanza mempertahankan posisi pada 2016, Xenia berada di peringkat ke-4. Hingga Desember 2018, Avanza masih di posisi pertama sementara Xenia berada di posisi ke 4 (Nayazri, 2018) dalam kategori MPV. Untuk LCGC, Cayla dan Sigra berada di posisi pertama dan kedua sebagai penjualan terbaik pada tahun 2017 dan 2018 (Makur, 2017; Muzlie, 2018).

Strategi co-branding ini berhasil membawa Avanza dan Xenia dan Calya dan Sigra sebagai merek teratas produk. Fenomena ini mendasari beberapa literatur bahwa produk co-branded menerima evaluasi yang lebih positif jika menggabungkan merek produk nasional terkenal (Irawan, 2014; Vaidyanathan \& Aggarwal, 
2000), dan dua merek ekuitas tinggi dipasangkan menghasilkan evaluasi yang lebih positif untuk setiap merek yang bermitra, bukan sebelumnya (Ahn \& Sung, 2012; Washburn, Till, \& Priluck, 2000). Lebih spesifik, produk berkualitas tinggi dari mitra merek meningkatkan evaluasi positif dari produk merek bersama atau merek yang lebih lemah (Besharat \& Langan, 2014; Helmig, 2008). Merek ekuitas yang lebih rendah mendapat manfaat lebih banyak dari aliansi daripada mitra ekuitas yang lebih tinggi dalam co-branding bisnis, sementara merek dengan tingkat ekuitas yang setara berbagi manfaat co-branding secara merata (Kalafatis et al. 2012). Penjualan terbaik dari empat merek juga memperkuat beberapa penelitian bahwa strategi co-branding membantu produk untuk membedakan dari pesaing (Ashton \& Scott, 2011). Toyota diasumsikan telah meningkatkan persepsi kualitas Daihatsu, sehingga baik Avanza dan Xenia dan Calya dan Sigra berjalan seiring dalam beberapa periode. Periode berikutnya, Avanza mampu bertahan di peringkat pertama sementara Xenia jatuh.

Deskripsi di atas menimbulkan pertanyaan mengapa ada tingkat penjualan yang berbeda antara produk co-branding. Seperti yang digambarkan di atas, adalah penerimaan bahwa strategi co-branding cocok untuk mendapatkan keuntungan melalui penciptaan kesadaran awal, keakraban, loyalitas pelanggan, dan, pembelian. Disisilain,strategico-brandingyangefektifsangat tergantung pada persepsi konsumen potensial daripada sepenuhnya dalam kendali pemasar (Clow \& Baack, 2010; Askegaard \& Bengtsson, 2005). Hipotesis dirumuskan sebagai berikut:

$\mathrm{H}_{1}$ : Meskipun identik, kedua merek bersama memiliki makna yang berbeda dari responden

$\mathrm{H}_{2}$ : Para responden mengungkapkan makna yang lebih positif terhadap Avanza daripada Xenia dan Calya daripada Sigra.

Penelitian saat ini memberikan kontribusi untuk mengembangkan studi co-branding di Indonesia karena hanya ada sedikit penelitian empiris kuantitatif pada subjek co-branding, meskipun produk co-branding telah digunakan untuk strategi komunikasi pemasaran (Helmig et al. 2008; Kalafatis et al. 2012).

\section{Metode Penelitian}

Penelitian inimenggunakan metode kuntitatif pendekatan survei yang menggunakan perbedaan semantik yang melibatkan tiga dimensi utama: evaluasi, aktivitas, dan potensi. Instrumen dari Colwell et al. (2008) dan Vigneron \& Johnson (2004) diadopsi untuk merumuskan kuesioner penelitian. Evaluasi adalah bagaimana individu mengevaluasi produk co-branding berdasarkan perhatian, keunikan, dan kualitas, sedangkan aktivitas adalah makna individu terhadap produk dan direpresentasikan sebagai hedonisme dan perluasan diri (Vigneron \& Johnson, 2004) dan kepuasan (Colwell et al. 2008). Potensi didefinisikan sebagai maknaindividuberdasarkan kenyamanan manfaat, kenyamanan keputusan, dan kenyamanan transaksi (Colwell et al. 2008).

Instrumen pokok yang digunakan dalam metode survei adalah kuesioner. Kuesioner dalam penelitian ini telah digunakan dalam beberapa penelitian yang lain, seperti (Kriyantono, 2017 dan Lukyandari, 2014) sehingga validitasnya sudah terbukti, yang berbeda adalah konteks penelitiannya. Kuesioner memasukkan beberapa item pernyataan seperti dijelaskan dalam Tabel 1.

Peneliti melakukan sebuah survei kepada 111 responden yang dipilih dengan menggunakan teknik convenience sampling. Responden penelitian merupakan orang-orang yang memiliki informasi tentang produk, yakni konsumen potensial, yang dipilih adalah mahasiswa sarjana dan magister komunikasi Universitas Brawijaya. Pemilihan konsumen potensial ini (bukan pembeli) dengan alasan untuk menggali pemaknaan internal orang yang belum membeli. Bagi yang sudah membeli maka dia sudah melakukan keputusan pembelian sehingga diasumsikan dapat berpengaruh pada pemaknaan internal saat dia diminta mengisi kuesioner. 
Table 1. Instrumen Penelitian

\begin{tabular}{|c|c|c|}
\hline $\begin{array}{l}\text { Osgood's } \\
\text { dimensions }\end{array}$ & Sub-dimensions & Items \\
\hline \multirow[t]{3}{*}{ Evaluation } & $\begin{array}{l}\text { Conspicuousness } \\
\text { (Vigneron \& Johnson, 2004) }\end{array}$ & $\begin{array}{l}\text { Ketertarikan produk, termasuk daya } \\
\text { tarik bagi konsumen }\end{array}$ \\
\hline & $\begin{array}{l}\text { Uniqueness } \\
\text { (Vigneron, \& Johnson, 2004) }\end{array}$ & Keunikan dan keeksklusifan produk \\
\hline & $\begin{array}{l}\text { Quality } \\
\text { (Vigneron \& Johnson, 2004) }\end{array}$ & Kualitas produk \\
\hline \multirow[t]{2}{*}{ Activity } & $\begin{array}{l}\text { Hedonism and extended } \\
\text { (Vigneron \& Johnson, 2004) }\end{array}$ & $\begin{array}{l}\text { Kreativitas dan kemampuan } \\
\text { masyarakat untuk mengidentifikasi }\end{array}$ \\
\hline & Satisfaction (Colwell, et al, 2008) & Impresi kesukaan konsumen \\
\hline \multirow[t]{3}{*}{ Potency } & $\begin{array}{l}\text { Benefit convenience (Colwell, et al, } \\
\text { 2008) }\end{array}$ & $\begin{array}{l}\text { Kemampuan produk untuk memenuhi } \\
\text { kebutuhan konsumen dan produk } \\
\text { tersebut sesuai untuk konsumen }\end{array}$ \\
\hline & $\begin{array}{l}\text { Decision Convenience } \\
\text { (Colwell, et al, 2008) }\end{array}$ & $\begin{array}{l}\text { Produk memberikan informasi } \\
\text { tentang manfaat dan keunikannya }\end{array}$ \\
\hline & $\begin{array}{l}\text { Transaction Convenience } \\
\text { (Colwell, at al, 2008) }\end{array}$ & Harganya terjangkau bagi konsumen \\
\hline
\end{tabular}

Sumber: Olah data peneliti (2019)

Penelitian ini merupakan pengembangan dari penelitian sebelumnya dari Kriyantono (2017). Pemilihan responden yang khusus dari kelompok mahasiswa dan penambahan dua merek co-branding dalam penelitian ini, yakni Sigra dan Cayla, untuk menambah objek yang pada penelitian sebelumnya hanya Avanza dan Xenia, merupakan pembeda dengan penelitian Kriyantono (2017) tersebut.

Perbandingan menggambarkan produk yang paling favorit dan menggambarkan apakah salah satu merek dominan atau sama dengan yang lain untuk menilai kekuatan atau ekuitas merek. Peneliti mencapai persentase skor ratarata menuju skor maksimum, nilai indeks, yang mewakili kualitas produk: kualitas rendah $(<25 \%)$; sedang (hingga 50\%); tinggi atau baik (hingga 75\%); dan sangat tinggi atau sangat baik (> 75\%) (Kriyantono, 2015). Skala pengukuran berasal dari skala diferensial semantik Osgood dengan tujuh titik skala yang menyatakan secara verbal dua rangkaian kata sifat bipolar yang berbeda, yaitu: baik-buruk; tinggi rendah; kuat lemah. Dalam rangkaian kata berkutub tersebut, responden diminta untuk memberikan tanda silang atau lingkaran pada angka yang sesuai, yakni; Bagus: 7 ; 6 ; 5; 4; 3 ; 2 ; 1, Buruk.

\section{Hasil Penelitian dan Pembahasan}

Seperti yang ditampilkan pada Tabel 3, secara umum, Toyota memiliki makna internal yang lebih baik daripada Daihatsu di kedua kategori mobil, MPV dan LCGC. Toyota Avanza memiliki nilai indeks lebih tinggi (77.73\%) daripada Daihatsu Xenia (74.5\%), sedangkan Toyota Calya memiliki nilai indeks lebih tinggi (75.33\%) daripada Daihatsu Sigra (72.67\%). Kedua produk Toyota berada dalam indeks sangat tinggi atau sangat baik ( $>75 \%)$, sedangkan dua produk Daihatsu berada dalam indeks tinggi atau baik (hingga 75\%). Temuan ini juga menunjukkan bahwa level indeks dari kedua merek bersama dikaitkan dengan posisi keduanya sebagai mobil yang paling laku di kategori mereka. 
Tabel 2. Mean scores diferensiasi semantik

\begin{tabular}{|c|c|c|c|c|c|c|c|c|c|c|}
\hline \multirow{2}{*}{ Dimensions } & \multirow[b]{2}{*}{ Sub-dimensions } & \multirow[b]{2}{*}{ Items } & \multicolumn{2}{|c|}{ Avanza } & \multicolumn{2}{|c|}{ Xenia } & \multicolumn{2}{|c|}{ Calya } & \multicolumn{2}{|c|}{ Sigra } \\
\hline & & & $\begin{array}{l}\text { Mean } \\
\text { Scores }\end{array}$ & Max scores & $\begin{array}{l}\text { Mean } \\
\text { Score }\end{array}$ & Max Scores & $\begin{array}{l}\text { Mean } \\
\text { Scores }\end{array}$ & Max scores & $\begin{array}{l}\text { Mean } \\
\text { Scores }\end{array}$ & Max Scores \\
\hline \multirow[t]{6}{*}{ Evaluation } & Conspicuousness & Product's attractiveness & 5.03 & 7.00 & 4.38 & 7.00 & 5.05 & 7.00 & 5.02 & 7.00 \\
\hline & Uniqueness & Product's uniqueness & 4.70 & 7.00 & 4.67 & 7.00 & 5.06 & 7.00 & 4.96 & 7.00 \\
\hline & & Product's exclusiveness & 4.99 & 7.00 & 4.00 & 7.00 & 5.25 & 7.00 & 5.07 & 7.00 \\
\hline & Quality & Product's quality & 5.46 & 7.00 & 5.36 & 7.00 & 5.31 & 7.00 & 5.09 & 7.00 \\
\hline & & Total & 20.18 & 28.00 & 18.41 & 28.00 & 20.67 & 28.00 & 20.14 & 28.00 \\
\hline & & Index Value & $72.07 \%$ & $100 \%$ & $65.75 \%$ & $100 \%$ & $73.82 \%$ & $100 \%$ & $71.92 \%$ & $100 \%$ \\
\hline \multirow[t]{6}{*}{ Activity } & Hedonism & Product's creativity & 5.13 & 7.00 & 5.11 & 7.00 & 5.96 & 7.00 & 5.17 & 7.00 \\
\hline & extended self & $\begin{array}{l}\text { Product's ability to create identity as } \\
\text { a family car }\end{array}$ & 6.11 & 7.00 & 5.98 & 7.00 & 4.96 & 7.00 & 4.92 & 7.00 \\
\hline & Satisfaction & Product's impression & 5.42 & 7.00 & 5.29 & 7.00 & 5.25 & 7.00 & 4.94 & 7.00 \\
\hline & & $\begin{array}{l}\text { Product's ability to create } \\
\text { lovingness }\end{array}$ & 5.33 & 7.00 & 5.15 & 7.00 & 4.72 & 7.00 & 4.62 & 7.00 \\
\hline & & Total & 21.99 & 28.00 & 21.53 & 28.00 & 20.89 & 28.00 & 19.65 & 28.00 \\
\hline & & Index Value & $78.53 \%$ & $100 \%$ & $76.89 \%$ & $100 \%$ & $74.60 \%$ & & $70.17 \%$ & $100 \%$ \\
\hline \multirow[t]{8}{*}{ Potency } & $\begin{array}{l}\text { Benefit } \\
\text { convenience }\end{array}$ & $\begin{array}{l}\text { Product's ability to satisfy the } \\
\text { consumer's need }\end{array}$ & 5.81 & 7.00 & 5.74 & 7.00 & 5.28 & 7.00 & 5.19 & 7.00 \\
\hline & & $\begin{array}{l}\text { Product is appropriate for the } \\
\text { consumers }\end{array}$ & 5.88 & 7.00 & 5.72 & 7.00 & 5.46 & 7.00 & 5.31 & 7.00 \\
\hline & $\begin{array}{l}\text { Decision } \\
\text { Convenience }\end{array}$ & $\begin{array}{l}\text { The product gives information about } \\
\text { the its benefits and usefulness }\end{array}$ & 5.78 & 7.00 & 5.59 & 7.00 & 5.37 & 7.00 & 5.29 & 7.00 \\
\hline & $\begin{array}{l}\text { Transaction } \\
\text { Convenience }\end{array}$ & Affordable price for the consumer & 5.66 & 7.00 & 5.59 & 7.00 & 5.56 & 7.00 & 5.47 & 7.00 \\
\hline & & Total & 23.13 & 28.00 & 22.64 & 28.00 & 21.67 & 28.00 & 21.26 & 28.00 \\
\hline & & Index Value & $82.60 \%$ & $100 \%$ & $80.85 \%$ & $100 \%$ & $77.67 \%$ & $100 \%$ & $75.92 \%$ & $100 \%$ \\
\hline & & Total mean scores & 65.30 & 84 & 62.58 & 84 & 63.28 & 84 & 61.05 & 84 \\
\hline & & Total index values & $77.73 \%$ & $100 \%$ & $74.5 \%$ & $100 \%$ & $75.33 \%$ & $100 \%$ & $72.67 \%$ & $100 \%$ \\
\hline
\end{tabular}

Sumber: Data primer diolah menggunakan SPSS (2019)

Data menunjukkan bahwa tingkat indeks yang sangat tinggi diperoleh oleh semua produk hanya dalam dimensi potensi karena Calya dan Sigra hanya memperoleh indeks tinggi makna internal untuk evaluasi dan aktivitas. Ini berarti bahwa dua pasang merek bersama ini dianggap memiliki kemampuan untuk memenuhi kebutuhan konsumen, memiliki kesesuaian untuk konsumen, memberikan informasi yang baik tentang manfaat dan kegunaannya, dan memiliki harga yang terjangkau.

Toyota yang dianggap lebih baik daripada Daihatsu di ketiga dimensi untuk kategori MPV dan LCGC, hipotesis pertama dalam penelitian ini dapat terbukti. Terbuktinya hipotesis pertama ini juga mengafirmasi konsepkonsep teoretis bahwa dua merek ekuitas tinggi dipasangkan menghasilkan evaluasi yang lebih positif untuk setiap merek yang bermitra (Ahn \& Sung, 2012; Washburn, Till, \& Priluck, 2000). Semua produk, kecuali Sigra, indeks tertinggi adalah potensi, diikuti oleh aktivitas, dan indeks terendah adalah evaluasi.
Indeks terendah dari Sigra adalah aktivitas. Peneliti menggambarkan skor rata-rata dari setiap dimensi. Dimensi evaluasi, keempat produk memiliki penilaian tertinggi dalam sub-dimensi yang sama, yaitu kualitas. Produk co-branding dalam kategori MPV (Avanza dan Xenia) memiliki kualitas yang lebih baik daripada dalam kategori LCGC (Calya dan Sigra), namun, kategori LCGC dianggap lebih eksklusif. Skor rata-rata yang lebih tinggi dari kategori LCGC dalam dimensi eksklusif tampak terkait dengan skor yang lebih tinggi dari LCGC dalam kreativitas produk. Hal ini dapat diartikan bahwa semakin kreatif semakin eksklusif mobil. Kemudian, di antara semua dimensi, LCGC memiliki makna internal yang lebih baik dalam dimensi evaluasi ini.

Dapat dikatakan bahwa responden menyatakan berbagai makna pada kedua pasangan produk co-branding namun mereka berpendapat bahwa produk co-branding ini memiliki potensi kualitas tertinggi. Untuk kualitas ini, semua produk memiliki skor rata- 
rata lebih dari 5.00. Secara umum, responden menganggap bahwa produk co-branding ini memiliki kemampuan untuk memenuhi kebutuhan konsumen, murah, oleh karena itu produk tersebut sesuai untuk konsumen. Tingginya skor kualitas karena produk dianggap mampu memenuhi kebutuhan ini tampak berkoneksi dengan tingginya penjualan kedua pasang produk co-branding ini. Dengan tingginya penjualan maka kedua pasang produk ini mampu meraih ekuitas merek yang baik. Beberapa literatur, seperti Kottler (2009) dan Kriyantono (2013) menyebut bahwa ekuitas merk berdampak positif bagi produsen dan konsumen. Produsen memiliki peluang besar untuk memproduksi produk dalam jumlah banyak dengan peluang penjualan yang tinggi dan, bagi konsumen, ekuitas merk bermakna bahwa merk tersebut mengandung jaminan kualitas produk dan manfaat tertentu yang dapat memenuhi kebutuhan dan keinginan konsumen.

Manfaat ini didukung oleh kemampuan produsen yang tinggi untuk mengomunikasikan karakteristik produk. Hal tersebut merupakan inti dari komunikasi pemasaran, yaitu, "komunikasi pemasaran harus lebih fokus pada penerima dan makna yang dibuat oleh penerima dalam proses komunikasi" (Finne \& Gronroos, 2009, h. 181), dengan menyampaikan pesan yang mengandung kebutuhan konsumen tentang manfaat dan kegunaan produk. Penelitian ini juga mengafirmasi penelitian sebelumnya bahwa cobranding komplementer memiliki lebih banyak kemampuan untuk membangun profil atribut yang lebih baik di benak konsumen daripada ekstensi merek langsung dari merek dominan atau produk merek bersama yang terdiri dari dua merek yang sangat menguntungkan tetapi tidak saling melengkapi (Helmig, et al, 2008).

Temuan peneliti menggambarkan bahwa Toyota Avanza memiliki level makna internal yang sangat tinggi sedangkan merek lain berada pada level tinggi. Hal ini membuktikan bahwa "hubungan co-branding yang sukses adalah hasil dari merek induk yang kuat, 'sesuai' antara merek induk, dan bahwa aliansi dianggap bermanfaat" (Dickinson \& Heath, 2008, h. 23). Toyota adalah merek induk yang kuat bagi Daihatsu sehingga ketika kedua produk yang sama (Toyota Avanza dan Daihatsu Xenia, Toyota Calya dan Daihatsu Sigra) pertama kali dipasarkan, Xenia dan Sigra dianggap sebagai produk yang baik.

Hasil penelitian semakin meneguhkan bahwa dengan merk yang sudah mapan, produsen dapat bebas dari hukum supply demand, yaitu jika permintaan naik, harganaik; jika permintaan turun harga turun. Dengan merk yang sudah terbentuk, berapa pun jumlah permintaan, produsen dapat menerapkan harga tinggi (Kriyantono, 2013).

Penelitian ini juga mengungkapkan bahwa meskipun kedua merek bersama memiliki makna yang berbeda dari responden, responden mengungkapkan makna yang lebih positif evaluasi, aktivitas, potensi - terhadap Avanza daripada Xenia serta Calya daripada Sigra, sehingga hipotesis kedua dapat diterima. Responden juga merasakan bahwa, untuk setiap kategori mobil, Avanza dan Calya memiliki lebih banyak kemampuan untuk memenuhi kebutuhan konsumen sebagai mobil keluarga sehingga dinyatakan sebagai mobil yang tepat untuk responden. Semakin tinggi penjualan co-branding ini juga ditentukan oleh karakter budaya konsumen. Orang Indonesia menerapkan budaya keluarga besar sehingga mereka lebih suka memilih kendaraan yang memiliki kemampuan untuk mengangkut sebanyak penumpang. Fakta ini membuktikan bahwa semua merek MPV di Indonesia memiliki penjualan tertinggi (Susanto, 2014).

Penelitian ini juga menetapkan bahwa Xenia dan Sigra berhasil memasuki pasar sepuluh terbaik karena evaluasi konsumen terhadap produk merek bersama tergantung pada sikap merek induk (Dickinson \& Heath, 2008; d'Astous \& Colbert, 2007), yakni Toyota yang memiliki kualitas produk yang lebih tinggi meningkatkan evaluasi positif Daihatsu, sebagai 
merek yang lebih lemah (Besharat \& Langan, 2014; Helmiq, 2008). Penelitian ini mendukung penelitian Kalafatis et al. (2012) bahwa perusahaan harus mempertimbangkan posisi ekuitas merek dari mitra co-branding potensial relatif terhadap posisi mereka sendiri. Jika dua perusahaan berbagi posisi ekuitas yang sama, mereka dapat mengharapkan untuk menikmati manfaat yang setara dari strategi pembuatan merek, terlepas dari seberapa kuat posisi ekuitas bersama. Peneliti menemukan bahwa Toyota menganggap ada pasar kosong untuk segmen berpenghasilan rendah dalam penelitian saat ini. Hal ini sesuai pendapat Cilfton (2003) bahwa "co-branding is an effective technique to reduce the cost of brand in entering the market and new geographic areas." Menurut Irawan (2012), Toyota meminta Daihatsu, produsen mobil kompak, untuk memproduksi Xenia. Toyota percaya bahwa setiap mobil yang diproduksi di bawah bendera Toyota berhasil.

Dapat dikatakan bahwa kedua pasang cobranding mendapatkan penjualan terbaik karena responden mempersepsikan lebih besar terhadap asosiasi fungsional dari produk, yakni responden merasakan atribut dan kapasitas pemecahan masalah dari masing-masing merek produk adalah serupa atau terkait (Ahn \& Sung, 2012). Asosiasi adalah seperangkat merek unik yang mengarah untuk membangun identitas merek dan pada akhirnya identitas merek secara sosial dibangun melalui interaksi kompleks antara berbagai pemangku kepentingan (Essamri, McKechnie, \& Winklhofer, 2019). Asosiasi merk yang unik ini merupakan positioning produk di benak konsumen (Kriyantono, 2013).

Produk co-branding sebagai rangsangan fisik Teori Osgood dimaknai sebagai konsumen maupun calon konsumen dari sisi evaluasi meliputi kemenarikan sebuah produk, keunikan, dan kualitas. Hal ini berarti ketika konsumen maupun calon konsumen memaknai sebuah produk co-branding maka yang ada di pikiran mereka adalah keunikan suatu produk cobranding tersebut, dan tentunya keunikan tersebut diukur dari produk co-branding secara keseluruhan baik dari brand, kemasan, dan layanan serta keistimewaan produk co-branding bagi calon konsumen maupun konsumen.

Ketiga faktor ini merupakan pemaknaan konotatif yang setiap orang lakukan, karena bersifat internal terhadap pengalaman seseorang dengan rangsangan alami. Teori Osgood yang membahas pemaknaan internal mengemukakan bahwa pemaknaan konotatif seseorang berada di suatu tempat dalam ruang hipotesis bergantung pada respon seseorang (Litllejohn et al. 2017). Dalam komunikasi pemasaran, strategi komunikasi pemasaran merupakan stimulus bagi munculnya respon tersebut.

Semua evaluasi konsumen tersebut sangat penting bagi produen. "To create brand equity, all consumer evaluation should be recalled and used as a guide to predict consumption behaviour of consumers" (McInnis, 2009). Strategi co-branding ini yang membuat ikut tingginya penjualan merek Daihatsu, tampat terkait dengan pendapat Davis (2009) bahwa cara membangun ekuitas merek adalah dengan mengubah nama atau detail merek.

Penelitian ini semakin memperkuat pentingnya aplikasi Teori Osgood dalam penelitian komunikasi pemasaran. Kajian komunikasi membahas bagaimana proses komunikasi yang melibatkan persepsi maupun kognisi, yang tercermin dalam tradisi sosiopsikologi. Teori-teori tradisi berfokus pada perilaku sosial individu, variabel psikologis, efek individu, kepribadian dan sifat, persepsi, serta kognisi (Craig, 2007; Littlejohn et al. 2017).

Pentingnya teori Osgood juga semakin membuktikan bahwa kajian pemasaran memang memiliki irisan dengan ilmu komunikasi. Di harapkan penelitian ini dapat memperkuat posisi komunikasi pemesaran sebagai sebuah disiplin yang semakin berkembang dalam kajian ilmu komunikasi. 


\section{Simpulan}

Penelitian ini mengafirmasasi hasil penelitian terdahulu bahwa meskipun dilakukan dalam koonteks kondisi yang berbeda, yakni responden yang berbeda dan kondisi lingkungan pemasaran yang memiliki pertambahan produk co-brand yang baru, hasil penelitian menunjukkan hasil yang tidak jauh berbeda. Penelitian ini mampu membangun hipotesis bahwa meskipun co-brand memiliki produk yang identik, mereka memiliki makna yang berbeda dari konsumen, dan konsumen mengekspresikan makna yang lebih positif - evaluasi, aktivitas, potensi - terhadap Avanza daripada Xenia dan Calya daripada Sigra. Temuan penelitian ini telah mengkonfirmasi beberapa studi mengenai co-branding bahwa strategi co-branding yang efektif ditentukan oleh beberapa faktor, seperti persepsi konsumen terhadap produk itu sendiri, merek induk, dan posisi ekuitas perusahaan atau merek. Hal tersebut dipengaruhi oleh kemampuan perusahaan untuk memenuhi produk dengan kebutuhan konsumen.

Penelitian ini dapat memperkaya studi tentang co-branding di Indonesia, meskipun masih mempunyai keterbatasan yang membatasi generalisasi dan menjadi peluang untuk dilakukan penelitian lebih lanjut. Studi ini menyelidiki co-branding antara dua merek dari perusahaan ekuitas tinggi, sehingga penting untuk memperluas penelitian ke merek produk yang sudah mapan. Penelitian di masa depan juga harus membantu menggambarkan generalisasi dari temuan ini dan lebih lanjut menentukan dampak dari berbagai responden, tidak hanya untuk konsumen potensial tetapi juga konsumen saat ini.

Metode kuantitatif, seperti penelitian eksperimental dan survei, dapat dilakukan untuk menyelidiki perspektif konsumen terhadap produk co-branding dengan memberikan berita tentang pengalaman baik atau buruknya perusahaan dalam penanganan krisis. Juga direkomendasikan untuk melakukan studi kualitatif. Penelitian etnografi juga dapat dilakukan untuk menggambarkan deskripsi yang kuat mengenai motif, perasaan, dan latarbelakang budaya konsumen mengenai produk co-branding.

\section{Daftar Pustaka}

Ahn, H., \& Sung, Y. (2012). A two-dimensional approach to between-partner fi $\mathrm{t}$ in $\mathrm{co}$ branding evaluations. Journal of Brand Management, 19(5), 414-424. https://doi. org $/ 10.1057 / \mathrm{bm} .2011 .49$

Askegaard, S., \& Bengtsson, A. (2005). When Hershey met Betty: Love, lust and cobranding. Journal of Product \& Brand Management, 14, 322-329. https://doi. org/10.1108/10610420510616359

Ashton, A. S., \& Scott, N. (2011). Hotel restaurant co-branding: The relationship of perceived brand fit with intention to purchase. Journal of Vacation Marketing, 17(4), 275-285. https://doi.org/10.1177/1356766711420838

Besharat, A., \& Langan, R. (2014). Towards the formation of consensus in the domain of co-branding: Current findings and future priorities. Journal of Brand Management, 21(2), 112-132. https://doi.org/10.1057/ bm.2013.25

Cao, Z. (2012). An empirical examination of stock market reactions to introduction of co-branded products. PhD Dissertation. Graduate Studies of Texas A \& M University. Clifton, R. (2003). The future of brand. In R. Clifton \& J. Simmons (Eds.), Brands and branding.London: The Economist.

Clow, K. E., \& Baack, D. (2010). Integrated advertising, promotion, and marketing communications. New Jersey: Pearson Education, Inc.

Colwell, S. R., May Aung., Kanetkar, V., \& Holden, A.L. (2008). Toward a measure of service convenience: multiple-item scale development and empirical test. Journal of Service Marketing, 160-169. https://doi. org/10.1108/08876040810862895

Craig, R, T. (2007). Communication as a field. In Craig, R.T \& Muller, H.L. (Eds.), Theorizing communication: Reading across traditions. London: Sage Publications.

D'Astous, A., \& Colbert, F. (2007). An experimental investigation of the use 
of brand extension and co-branding strategies in the arts. Journal of Service Marketing, 21(4), 231-240. https://doi. org/10.1108/08876040710758531

Dickinson, S., \& Heath, T. (2008). Cooperative brand alliances: How to generate positive evaluations. Australian Marketing Journal, 16, 22-40. https://doi.org/10.1016/S14413582(08)70012-0

Davis, M. (2009). The fundamentals of brandings. London, AVA Publishing.

Essamri, A., McKechnie, S., \& Winklhofer, H. (2019). Co-creating corporate brand identity with online brand communities: A managerial perspective. Journal of Business Research, 96, 366-375. https://doi. org/10.1016/j.jbusres.2018.07.015

Finne, A., \& Gronroos, C. (2009). Rethinking marketing communication: From integrated marketing communication to relationship communication. Journal of Marketing Communications, 15 (2-3), 179-195. . https:// doi.org/10.1080/13527260902757654

Finstuen, K. (1977). Use of Osgood's semantic differential. Psychological Reports, $41, \quad 1219-1222 . \quad$ https://doi.org/10.2466/ pr0.1977.41.3f.1219

Gunawanti, P. D. (2013). Pengaruh Penetapan Harga Dan Fitur Produk Terhadap Keputusan Pembelian: Survei Pada Konsumen Pengguna Mobil Toyota Avanza Dan Daihatsu Xenia Yang Melakukan Pembelian Dengan Sistem Kredit Di PT Astra Credit Companies Di Kota Bandung (Thesis. University of Indonesia, Jakarta). Retrived from http://repository.upi.edu/3949/

Griffin, E.M.(2013). Afirst lookatcommunication theory. New York: McGraw Hill.

Guillet, B. D., \& Tasci, A. D.A.(2010). Travellers' take on hotel-restaurant co-branding: Insights for China. Journal of Hospitality \& Tourism Research, 34(2), 143-163. https:// doi.org/10.1177/1096348009350618

Heding, T., Knudzten, J.F.,\& Bjerre, M. (2009). Brand management: Research theory and practice. New York, Routledge.

Helmig, B., Huber, J., \& Leeflang, P. (2008). Co-branding: The state of the art. Cobranding, SBR, October, 359-377. https://doi. org/10.1007/BF03396775

Irawan, H. (2012). Kijang, Avanza, dan Xenia. Frontier Consulting Group. Retrived March 28, 2016, from http://www.frontier.co.id/ kijang-avanza-dan-xenia.

Istiharini. (2006). Co-branding. Journal of Bina Economy, 10(1), 116-121. Retrived from https://media.neliti.com/media/ publications/27741-ID-co-branding.pdf

Kalafatis, S. P., Remizova, N., Riley, D., \& Singh, J. (2012). The differential impact of brand equity on B2B co-branding. Journal of Business \& Industrial Marketing, 27(8), 623-634. https://doi. org/10.1108/08858621211273574

Khan, K. (2007). User experience in mobile phone by using semantic differential methodology. Journal of Marketing Research, 143-150.

Kotler, P. (2009). Marketing Management. New York: Prentice Hall

Kriyantono, R. (2013). Manajemen periklanan. Malang: UB Press.

Kriyantono, R. (2015). Public relations and corporate social responsibility in mandatory approach era in Indonesia. Procedia - Social and Behavioral Sciences, 211, 320-327. https://doi.org/10.1016/j.sbspro.2015.11.041

Kriyantono, R. (2017). Consumers' internal meaning on complementary co-branding product by using Osgood's theory of semantic differential. Journal of Management and Marketing Review, 2(2), 57-63. Retrived from https://ideas.repec.org/p/gtr/gatrjs/ jmmr140.html

Lukyandari, D. D. A. (2014). Teori Osgood dalam pemaknaan internal produk cobranding. Universitas Brawijaya. Retrived from https://www.academia.edu/9198183/ TEORI_OSGOOD_DALAM PEMAKNAAN INTERNAL_PRODUK_CO_BRANDING Studi Deskriptif Kuantitatif pada Produk 
Co branding IM3 Arema

Kurniawan, A., Suryoko, S., \& Listyorini, S. (2014). Pengaruh strategi co-branding, brand equity terhadap purchase intention melalui brand preference. Jurnal Administrasi Bisnis, 3(4), 1-7. https://ejournal3.undip.ac.id/ index.php/jiab/article/view/6253

Leuthesser, L., Kohli, C., \& Suri, R. (2003). $2+2=5$ ? A framework for using cobranding to leverage a brand. Journal of Brand Management, 11(1), 35-48. Retrived from https://www.academia. edu/25684576/2_2_5_A_framework_for using co branding to leverage a brand

Littlejohn, S. W., Foss. K. W., \& Oetzel, J. G. (2009). Theories of human communication. Illinois: Waveland Press.

McInnis, D.J., Park, C.W., \& Priester, J.R. (2009). Hand book of brand relationship. United States Of America, Library of Congress Cataloging-in-Publication Data.

Murdaningsih, D. (2016). Mengapa Avanza lebih laku dibanding Xenia. Retrived January 28, 2016, from https://republika.co.id/berita/ otomotif/mobil/16/01/28/o1nhjh368-mengapaavanza-lebih-laku-dibanding-xenia

Nayazri, G. M. (2016). Toyota avanza masih amankan gelar mobil terlaris. Kumparan, December 18, 2018.

Osgood, C. E., Suci G.C., \& Tannenbaum, P.H. (1957). The Measurement of meaning. Urbana, IL: University of Illinois Press.

Sharpe, L. K., Anderson, W. T. (1972). Conceptscale interaction in the semantic differential. Journal of Marketing Research, 432.

Singh, J., Kalafatis, S. P., \& Ledden, L. (2014). Consumer perceptions of cobrands: the role of brand positioning strategies. Marketing Intelligence \& Planning, 32(2), 145-159. https://doi.org/10.1108/MIP-03-2013-0055

Susanto, A. B. (2014). Mengubah merek, mengubah persepsi. Retrived The Jakarta Consulting Group, February 1, 2014. From http://www.jakartaconsulting.com/publications/ articles/bizmark/mengubah-merk-mengubahpersepsi.

Sreejesh, S. (2012). Consumers' evaluation of co-brand extensions: The effects of concept congruity on the evaluation of co-branded products, analysing the moderating role of task involvement. International Management Review, 8(1), 21-34. Retrived from https:// www.semanticscholar.org/paper/Consumers'Evaluation-of-Co-Brand-Extensions\%3A-TheSreejesh/9c1801c202d6621e498f325f33de0 $\underline{5 f 646576412}$

Strunga, A. C. (2014). Osgood's semantic differential: A review of the Romanian social sciences literature. Social Sciences and Education Research Review, 2, 22-28. Retrived from http://www.alexstrunga.ro/ papers/paper_7_2014.pdf

Vaidyanathan, R., \& Aggarwal, P. (2000), Strategic brand alliances: Implications of ingredient branding for national and private label brands. Journal of Product \& Brand Management, 9, 214-228. https://doi. org $/ 10.1108 / 10610420010344013$

Vigneron, F., \& Johnson, W. L. (2004). Measuring perception of brand luxury. Journal of Brand Management, 11(6), 484-507. Retrived from https://www.researchgate.net/profile/ Franck_Vigneron/publication $/ 31968013$ Measuring_perceptions of brand luxury/ links/5654c25608ae1ef92976dfe0/Measuringperceptions-of-brand-luxury.pdf

Washburn, J. H., Till, T. B., \& Priluck, R. (2000). Co-branding: Brand equity and trial effects. Journal of Consumer Marketing, 17(7), 591-604. Retrived from https://www.museum. brandhome.com/docs/P0082_Co-branding\%20 - $\% 20$ brand $\% 20$ equity $\% 20$ and $\% 20$ trial $\% 20$ effects.pdf

Wheeler, A. (2009). Desinging brand identity $\left(3^{r d} e d\right)$. San Francisco: John Wiley \& Son Inc. 